\title{
Analysis Of Question Papers In Engineering Courses With Respect To Hots (Higher Order Thinking Skills)
}

Sowmya Narayanan, School of Social Sciences and Languages, VIT University, Vellore, Tamil Nadu, India M. Adithan, Academic Staff College, VIT University, Vellore, Tamil Nadu, India

\begin{abstract}
It is generally perceived that a substantial number of engineering faculty are still unaware of alternative educational methods, and many who are aware of them choose not to incorporate them into their approach to teaching. There are several likely reasons for this inertia, aside from the inevitable human resistance to change. The primary focus of imparting information is restricted to fulfilling the course requirements and, the upcoming term end examination. It is imperative to adopt a change from teaching to learning paradigm engaging the students in Higher Order Thinking Skills. Knowledge and technological advancements are changing the role of engineering and engineering faculty in the society. Engineering Education reforms need to focus on inductive teaching and stimulated learning. Students should be taught critical thinking skills and creative thinking skills to keep pace with the rapidly changing engineering profession.
\end{abstract}

This paper reports the study done to test and explore the faculty awareness of Bloom 's Taxonomy of Educational Objectives in the cognitive domain and Higher Order Thinking Skills (HOTS) and to evaluate question papers set by engineering faculty with respect to HOTS as proposed by Bloom's Taxonomy. Various active learning strategies to enhance critical thinking skills and creative thinking skills of the students are recommended for use by the faculty in their interactions with the students.

Keywords: Bloom's Taxonomy; Higher Order Thinking Skills (HOTS); Critical Thinking; Creative Thinking; Analysis of Question Papers

\section{INTRODUCTION}

lobalization, demographics and technological advances are changing the role of engineering and technology in society (Duderstadt, 2008). ${ }^{1}$ Outsourcing which was restricted to call centers in India, hitherto, is now seen in engineering design, $\mathrm{R} \& \mathrm{D}$ and even in innovation. The change that is required is a shift from routine, repetitive aspects of engineering to higher order and more value added activities. According to former US Secretary for Education, Richard Riley the top ten jobs that will be in demand in 2020 did not exist in $2010{ }^{2}$ It is predicted that by 2020 information will double every 72 hours. A change needs to occur in the current post primary education from knowledge acquisition and lower cognition to knowledge application and higher cognition knowing when and how to use that knowledge. ${ }^{3}$ Learners of the $21^{\text {st }}$ century need to develop new skills and that the three R's, reading writing, and arithmetic are no longer enough. According to Gluck in Peters (1994) ${ }^{4}$ we must add in our list the three C's Computing, Critical Thinking and Capacity for Change as well.

Faculty and educators should not allow the students to wonder whether they have been learning anything that would actually serve them in the workplace, upon graduation. ${ }^{5}$ Traditionally engineering curriculum focused on deductive instruction where the instructors, delivered lectures with limited application of the principles to real life engineering. Deductive instructional approaches have limitations in preparing engineers for a changing global society as required by NAE (National Academy of Engineering), (2005). ${ }^{6}$ Engineering Education reforms need to focus on inductive teaching and situated learning which involves student engagement in real life problem solving as 
opposed to disconnected lectures fulfilling curricular requirements. ${ }^{7}$ An inductive approach with situated learning involves inquiry learning, problem based learning, vignette instruction and case based instruction. (Prince and Felder, 2006). ${ }^{8}$ The pedagogic techniques practiced in many engineering colleges and technical institutions in India, though are aimed to meet the goal of cognitive development amongst the students but often end up in meeting the requirements of an examination system designed to test the rote memory rather than developing problem solving skills. (Sowmya Narayanan and Adithan. M, 2012). ${ }^{9}$

Academic Staff College at VIT University has been conducting a number of Faculty Development Programmes (FDP'S) on Bloom's Taxonomy and Revised Bloom's Taxonomy to train its faculty on the use of them as an assessment and pedagogical tool. In order to improve student's higher order thinking skills, teachers should employ suitable teaching and assessment methods. Anderson and Krathwohl (2002) ${ }^{10}$ categorises knowledge as factual knowledge, conceptual knowledge, procedural knowledge, and meta cognitive knowledge. These are remembering, understanding, analyzing, evaluating and re organizing in the cognitive process dimension. In the present study the focus is on Bloom's original taxonomy only. Bloom's taxonomy deals with three dimensions viz cognitive, emotive and psychomotor. In this research Bloom's taxonomy of educational objectives pertaining to cognitive domain alone is considered and reported. There is a need to identify the teacher's ability to prepare questions at various levels of the taxonomy and offer the requisite training programmes to fulfill that need.

The purpose of the study was to know the extent of awareness of Bloom's Taxonomy and Higher Order Thinking Skills (HOTS) amongst the engineering faculty and to analyze the end- semester question papers with respect to HOTS as proposed by Bloom's Taxonomy. The study brings out the importance of critical thinking and creative thinking amongst the engineering faculty and how these skills can be incorporated in the teaching-learning process.

\section{BLOOM'S TAXONOMY OF EDUCATIONAL OBJECTIVES OF THE COGNITIVE DOMAIN}

Benjamin Bloom in 1956 proposed a Taxonomy of Learning Objectives of the Cognitive Domain. This work has been extensively used and referred to by researchers, teachers, educationists, curriculum planners and examiners, almost at all levels of education in several disciplines. (Anderson and Sosnaik 1994). ${ }^{11}$ The objectives are placed in a hierarchy starting from Knowledge to Evaluation Fig 1. The first three levels namely knowledge, comprehension and application are generally known as LOTS (Lower Order Thinking skills) while, analysis, synthesis and evaluation are termed HOTS (Higher Order Thinking Skills). The levels have been a stairway leading many teachers to encourage their students to climb a higher level of thought. However, according to the authors, in engineering education, the level "application" needs to be positioned in HOTS since students of engineering and technology are expected to know the engineering and technological applications of the various theories, principles and concepts that they learn while studying the various subjects. There is a need to sensitize the engineering faculty on this critical aspect.

Bloom's Original Taxonomy

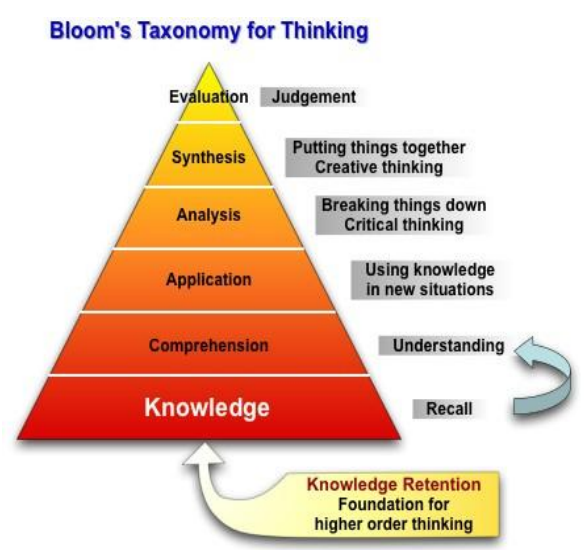

Bloom's Revised Taxonomy

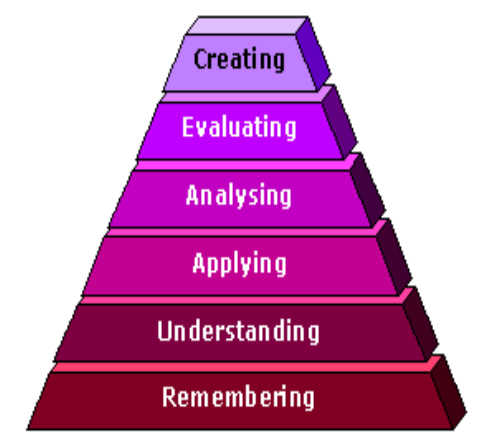

Figure 1. Bloom's Taxonomy of Educational Objectives (Cognitive Domain) 
The taxonomy is hierarchical; each level is subsumed by the higher levels. In other words, a student working at the application level has also mastered the material at the knowledge and comprehension level. (University of Wisconsin, Teaching Academy, 2003) ${ }^{12}$.

When the instructor desires to move a group of students through a learning process, utilizing an organized framework of Bloom's Taxonomy can be quite helpful. It has been linked with Multiple Intelligences, problem solving skills, Creative and Critical thinking and more recently technology integration skills.

In engineering subjects teachers can develop the critical thinking skills of the students using Bloom's Taxonomy. A teacher can ask more questions at the analysis and synthesis level than a simple recall of facts at the knowledge level. "Students can incorporate the ability to analyze, synthesize or evaluate the concepts for which there should be an increase in their learning and understanding resulting in enhanced retention of the subject matter taught and ability to apply them in real life situations.'(Cruz, 2004) ${ }^{13}$

\section{BLOOM'S REVISED TAXONOMY LEVELS AND CORRESPONDING ILLUSTRATIVE VERBS (Appendix 1)}

\begin{tabular}{ll}
\hline \multicolumn{1}{c}{ Levels } & \multicolumn{1}{c}{ Illustrative Verbs: } \\
\hline $\begin{array}{l}\text { Knowledge: Can the student recall or remember the } \\
\text { information? }\end{array}$ & define, duplicate, list, memorize, recall, repeat, reproduce, state \\
\hline Comprehension: Can the student explain ideas or concepts? & $\begin{array}{l}\text { classify, describe, discuss, explain, identify, locate, recognize, } \\
\text { report, select, translate, paraphrase }\end{array}$ \\
\hline $\begin{array}{l}\text { Application: Can the student use the information in a new } \\
\text { way? }\end{array}$ & $\begin{array}{l}\text { choose, demonstrate, dramatize, employ, illustrate, interpret, } \\
\text { operate, schedule, sketch, solve, use, write. }\end{array}$ \\
\hline $\begin{array}{l}\text { Analysis: Can the student distinguish between the different } \\
\text { parts? }\end{array}$ & $\begin{array}{l}\text { appraise, compare, contrast, criticize, differentiate, } \\
\text { discriminate, distinguish, examine, experiment, question, test. }\end{array}$ \\
\hline $\begin{array}{l}\text { Synthesis: Can the student create/develop a new product or } \\
\text { point of view? }\end{array}$ & $\begin{array}{l}\text { assemble, construct, create, design, develop, formulate, write. } \\
\begin{array}{l}\text { Evaluate: Can the student justify a particular statement or } \\
\text { decision? }\end{array}\end{array}$ \\
\hline
\end{tabular}

Thus, Bloom's Taxonomy will serve as an effective tool guiding the faculty to arouse the curiosity of learners in their subjects. A faculty needs to develop a repertoire of questions that generate higher order thinking skills such as the following. What do you already know? What do you think really about this situation?

\section{CRITICAL THINKING AND CREATIVE THINKING}

"Critical thinking is the disciplined mental activity of evaluating arguments or propositions and making judgments that can guide the development of beliefs and taking action."(Huitt 1998) ${ }^{14}$ Evaluating is, considered equivalent to critical thinking and this focuses on making assessment or judgment based on an analysis of a statement or proposition. Learning the process of critical thinking might be best facilitated by a combination of didactic instruction and experience in specific content areas.

"Creative thinking requires an individual to look at parts and relationships (analysis) and then to put these together in a new and novel way, as well as looking at the elements and the whole in a new perspective altogether". (Huitt) ${ }^{14}$ "Techniques that are often taught as part of critical thinking process is generally more linear and serial, more structured, more rational and analytical and goal oriented. Techniques taught as part of creative thinking exercises tended to be more holistic, and parallel, more emotional and intuitive, more creative, more visual, more kinesthetic. This distinction relates to what is sometimes referred to as left brain thinking (analytic, serial, logical, objective) as compared to right brain thinking (global, parallel, emotional, subjective)" (Springer and Deutsch, $1993)^{15}$. Engineering faculty needs to be exposed to these concepts during the Faculty Development Programmes. 


\section{ENHANCING CRITICAL THINKING SKILLS}

All higher educational institutions (HEI's) and Universities should enhance critical thinking skill amongst their students and should be held accountable for to provide this when students are enrolled and pursuing a degree programme. "Active learning, which includes activities such as discussion, debates, role plays and cooperative learning encourages critical thinking and helps the students retain technical contents better. When active learning activities are employed, students have to use a deep level approach when learning course contents, which results in students using higher order thinking skills. (Annette Mallory Donava, 2003) ${ }^{16}$

\section{OBJECTIVES OF THE STUDY}

The aim of the present study was twofold. First was to test and explore the faculty's awareness of Bloom's Taxonomy and HOTS, and the second was to evaluate/analyze their question papers with respect to HOTS as proposed by Bloom's Taxonomy. In a higher institution or university set up, it is expected that \% of questions in end-semester examinations constituting HOTS should be about 70-75\% and students are expected to attain this level of competency and learning outcomes.

\section{RESEARCH POPULATION}

For conducting this study the research population identified were faculty teaching engineering courses from four colleges of engineering and technology in the region; three colleges from University affiliated systems and Schools of Engineering from VIT University itself.

Responses with respect to extent of awareness of Bloom's taxonomy and its various levels were obtained from a total of 104 faculty members across various disciplines/subjects in engineering and technology. The sample population involved in the study in the pre and post workshop surveys remains the same i.e. 104 faculty.

\section{RESEARCH METHODOLOGY}

The study is based on the analysis of responses of faculty participants. In the first part of the research study a Questionnaire (as in Table 1) was administered to the faculty members to elicit their awareness of Bloom's taxonomy and its various levels. The reason for this is it is generally observed that engineering faculty in Indian technical institutions and colleges of engineering are not aware of Bloom's taxonomy, since they have not gone through any formal structured pedagogical training programme prior to their appointment as engineering faculty. Then, sessions on Bloom's Taxonomy were held as part of training programme to enhance and to improve their awareness and knowledge of Bloom's taxonomy as a pedagogical tool. Training programmes on Bloom's taxonomy were conducted for faculty working in the engineering colleges, functioning within a University Affiliation system as well as to faculty working in different schools at VIT University. Number of question papers analyzed and the mean $\%$ of questions involving LOTS and HOTS are given in Table 5.

After the training programme the questionnaire with the same contents was administered to know the extent of their awareness. Responses were analyzed with respect to both quantitative and qualitative aspects and summarized in Table 2.

The second part of the research study was the analysis of end- semester question papers prepared by the faculty. For this purpose a proforma (Table 3) was developed and given to faculty. Faculty were asked to study the question paper set by them and identify to which category a particular test item/question belongs to and indicate the marks allotted to the question. The data obtained was tabulated as in Table 3. The \% of questions of various levels of the cognitive domain i.e. knowledge and comprehension constituting LOTS and application, analysis, synthesis and evaluation constituting the HOTS are shown as in Table 4. 
Table 1. Questionnaire Administered Before And After Training Sessions On Bloom's Taxonomy

\begin{tabular}{|l|l|}
\hline Name: & Date: \\
\hline Designation: & \\
\hline School: & \\
\hline Name of the theory Subject/Course you are handling this Semester Dec. 2011-April 2012 \\
\hline Name of the Programme and Branch: \\
\hline Have you attended any lecture/sessions on Bloom's Taxonomy earlier? \\
\hline Name some levels of Bloom's taxonomy? \\
\hline What is LOTS? Expand \\
\hline What is HOTS? Expand \\
\hline Are you aware of alternate approaches to learning? \\
\hline If yes, list the alternate approaches you know. \\
\hline
\end{tabular}

Table 2. Analysis Of Responses Received

\section{No. Of Responses Received Colleges Participated}

- Sahrdaya College of Engineering \& Technology, Kodakkara affiliated to University of Calicut

- St. Ann's College of Engineering and Technology, Chirala affiliated to Jawaharlal Nehru Technological University, Hyderabad

- Abdul Hakeem College of Engineering, Melvisharam affiliated to Anna University, Chennai

- VIT University (Engineering Schools), Vellore

Total 104

No. Of Faculty Involved:

26

27

26

25

104

Before The Training Sessions

After The Training Sessions (no. of responses)

Have you attended any lecture/session $\quad$ Yes -11 (10.6\%) on Bloom's Taxonomy earlier?

- How many levels are there in Bloom's Taxonomy?

- What is LOTS? Expand

- What is HOTS? Expand

- Are you aware of alternate approaches to learning?

No-93 $(89.4 \%)$

95 (91.3\%) participants did not know the no. of Levels.

98 (94.2\%) participants did not know the expansion of LOTS.

$98(94.2 \%)$ participants did not know the ex pansion of HOTS.

Yes $55(52.9 \%)$

No $49(47.1 \%)$
$5(4.8 \%)$ participants did not know that there are six levels even after the training session.

15 (14.4\%) participants didn't recollect the expansion of LOTS even though they attended the training session. $14(13.5 \%)$ participants didn't recollect the expansion of HOTS even though they attended training session. $83(79.8 \%)$ $21(20.2 \%)$ 
Table 3. Analysis Of Question Papers With Respect To Higher Order Thinking Skills (HOTS)

And Lower Order Thinking Skills (LOTS)

(numbers indicate the marks allotted to the question)

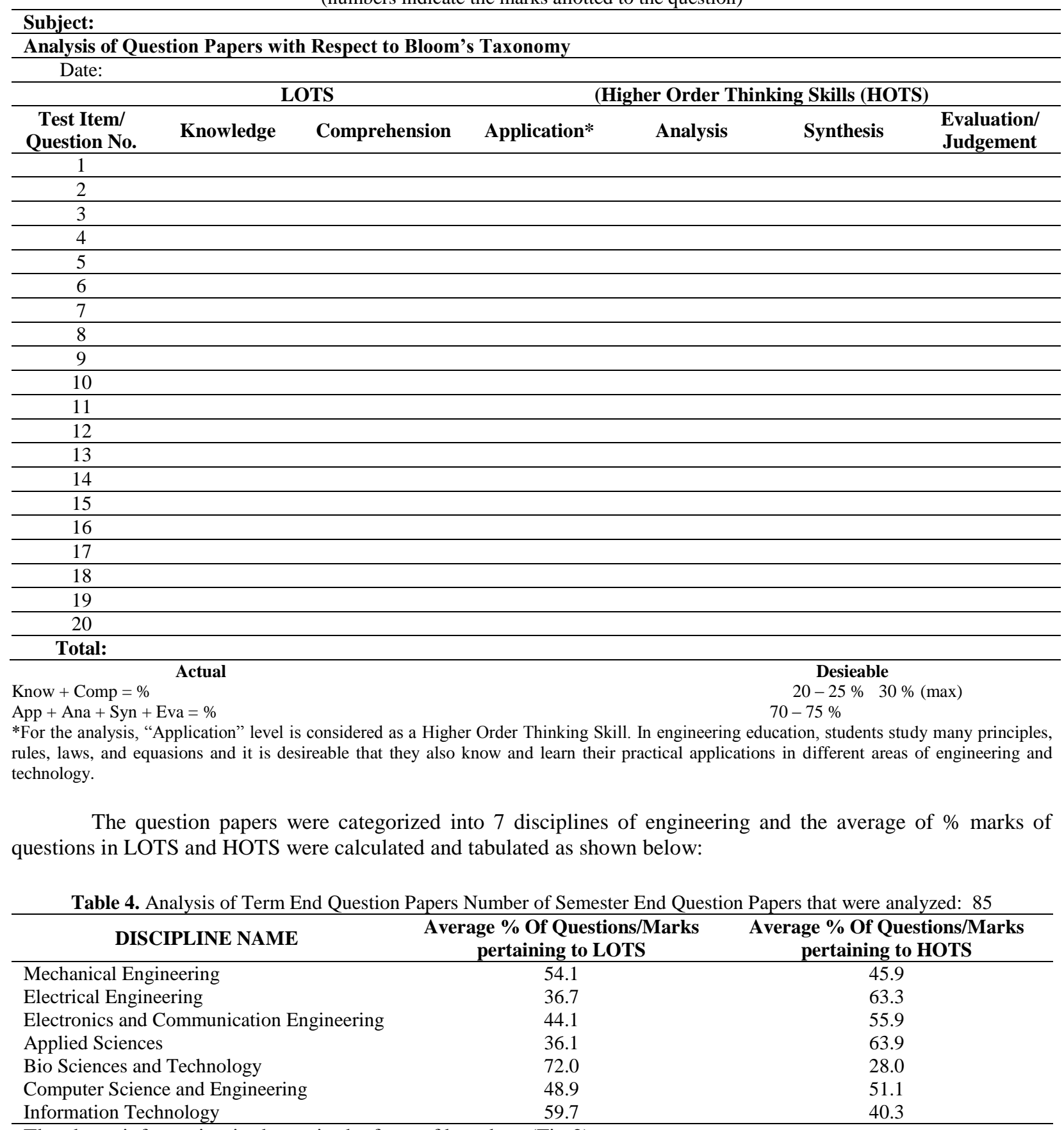

The above information is shown in the form of bar chart (Fig 2) 


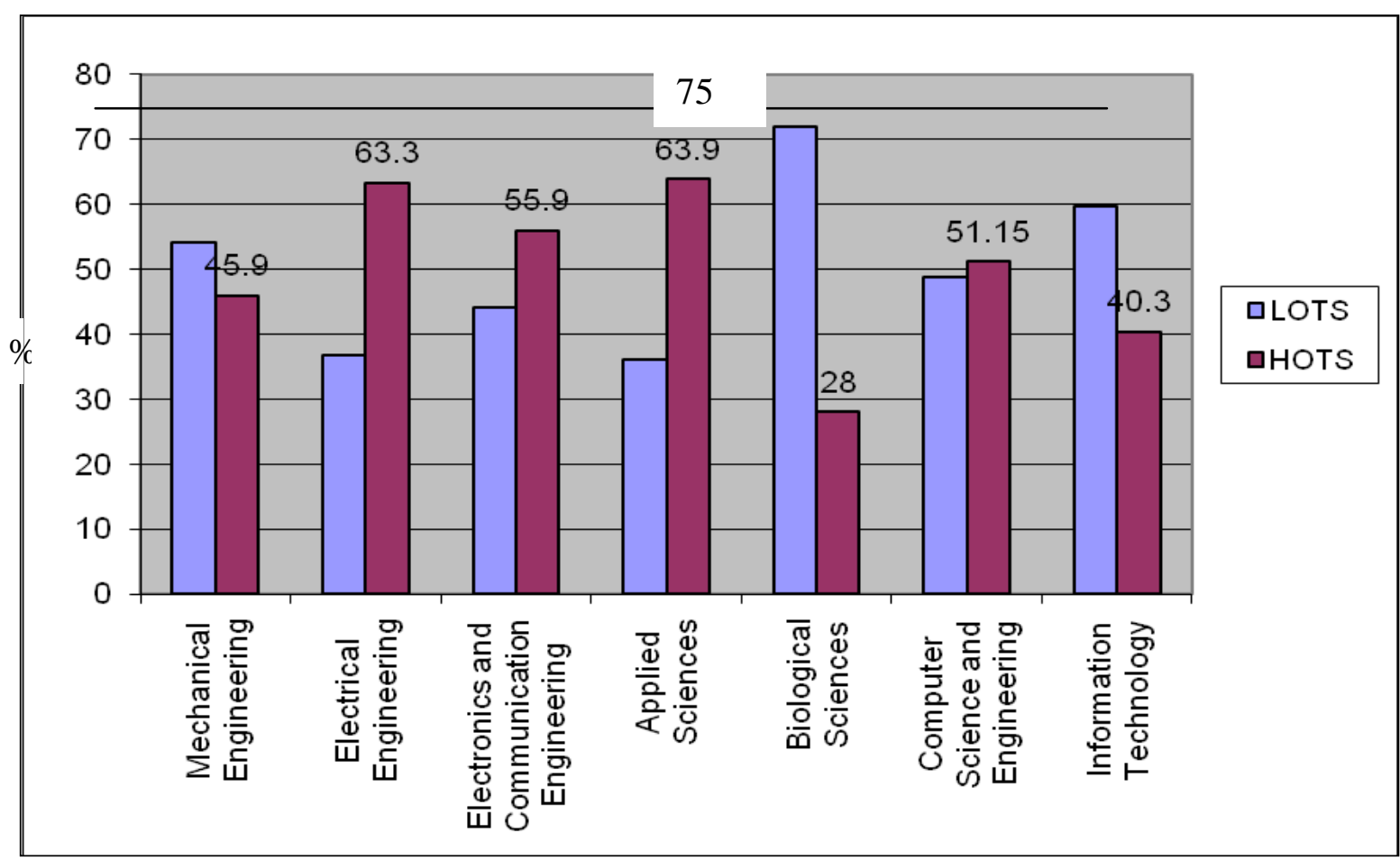

Figure 2. Analysis of Term End Question Papers In Respect Of Subjects across Various Disciplines \% indicated is in respect of HOTS only (75\% line indicates the expectation of the University i.e. proportion of questions constituting HOTS should be $75 \%$ )

Table 5. Analysis Of \% Questions Involving LOTS And HOTS Set

The findings are as follows:

By The Faculty Of Various Engineering Colleges And Engineering Schools

\begin{tabular}{lcc}
\multicolumn{1}{c}{ Name Of The College } & $\begin{array}{c}\text { Number Of Question } \\
\text { Papers Analysed }\end{array}$ & $\begin{array}{c}\text { Mean \% Of Questions } \\
\text { Involving Hots }\end{array}$ \\
\hline $\begin{array}{l}\text { *Sahrdaya College Of Engineering And } \\
\text { Technology }\end{array}$ & 25 & 58 \\
\hline *St Anns College Of Engineering And & 23 & 51 \\
Technology & 17 & 45 \\
\hline *Abdul Hakeem College Of Engineering & 20 & 53 \\
\hline *VIT University (Engineering Schools) & $\mathbf{8 5}$ & \\
\hline Total & Engineering Colleges functioning within an university affiliation system, but located in different towns \\
** Schools of engineering functioning within VIT University campus.
\end{tabular}

\section{RESULTS AND DISCUSSION}

HOTS (Higher Order Thinking Skill) is the ability to make judgments, analyze contents and synthesize information into coherent forms of communication and present such information to others. There are many examples/activities which illustrate the Higher Order Thinking Skills (Appendix 1). These aspects are discussed during the training sessions organized by the authors during this study. The awareness and knowledge of engineering faculty regarding Bloom's Taxonomy, LOTS and HOTS is abysmally low and hence there is a need to organize more training programmes of this kind.

The importance of setting good quality question papers with a high proportion of HOTS needs to be stressed amongst the engineering faculty during the faculty development programmes. A substantial number of engineering professors are still unaware of alternative educational methods, and many who are aware of them choose not to incorporate them into their approach to teaching. There are several likely reasons for this inertia, aside from the inevitable human resistance to change. On the job training preferably under the guidance of a senior faculty 
will also be of help in adopting the new methodologies. A total of 104 faculty participants across several disciplines of engineering were involved in this study. $89 \%$ of faculty participants have not attended a lecture/training session of this kind before and $91 \%$ of the respondents were not aware of the different levels in Bloom's Taxonomy. 94\% did not know the expansion of LOTS and HOTS before the training. This proportion is reduced to $14 \%$ after training. Before the training $47 \%$ of the respondent faculty members were not aware of the alternate teaching methods like role plays, quizzes and use of demonstrations. After the training this percentage reduced to $20 \%$. Thus the training sessions have given sufficient awareness and inputs in helping the faculty to understand Bloom's Taxonomy and its levels also various alternate strategies towards learning.

An analysis of end -semester question papers with respect to assessing the proportion of questions involving HOTS pertaining to engineering subjects has yielded interesting results. There is an expectation in engineering education as in VIT University that \% of questions/test items involving HOTS should be about $70-75 \%$ and the balance $25-30 \%$ could be from LOTS, so that skills such as Problem Solving, Critical thinking and Creative thinking are imparted and evaluated in engineering education.

Questions based on HOTS are more (above 63\%) in the case of disciplines like Applied Sciences; and Electrical Engineering. Questions based on HOTS are less in the case of disciplines like Bio Sciences, Computer Science, Information Technology and Electronics and Communication Engineering and Mechanical Engineering. In respect of these disciplines the low \% of HOTS could be due to the nature of curriculum presently followed at the University and/or due to inadequate exposure of faculty to the concept of HOTS in the teaching-learning process.

\section{CONCLUSIONS}

1. Faculty should be trained to set more questions testing the Higher Order Thinking Skills of the students. The faculty should pose questions to encourage critical thinking and creative thinking rather than asking students to recall from memory, facts or the general information.

2. The problems of the real world of work and engineering practice do not lend themselves so easily to a set of well defined questions. Most of the time the practical problems in the world of work remain indeterminate and are problems not too well defined confining to any equation or formula. This ability to formulate, evolve and understand the practical problem itself is quite a challenging task. These aspects need to be addressed at the highest level of Bloom's Taxonomy. We find that faculty is not able to train their students with abilities required to meet the challenges of the present and future engineering profession. This stresses the need and importance of faculty development programmes on critical thinking and creative thinking.

3. The proportion of questions pertaining to HOTS is much less than the expectation of the university/higher education institutions. Faculty needs to be sensitized on this pedagogical issue, since the analysis of question papers was done by the faculty themselves who have set the question papers.

4. Faculty need to be given more training sessions and orientation on Bloom's Taxonomy and also to be exposed to alternate and innovative teaching and learning processes. This would help the students think critically and creatively whereby subjecting the students to higher order questions would yield effective results.

5. Achievement at the lower levels of taxonomy, knowledge and comprehension learning can be facilitated by presenting facts, procedures and information to learners. For this instructional methods include lectures, viewing videos, and use of multimedia learning packages/ tutorials. However, achievement of skills at higher levels of Bloom's Taxonomy requires more active strategies. This requires the student to interact with information. Thus there must be opportunities for active learner participation, continuous practice and finally feedback and interaction. Majority of the questions in subjects like Bio Sciences and Technology, Computer Science, Information Technology, Electronics and Communication engineering and Mechanical Engineering require recall or memorizing ability and factual information, only testing surface knowledge. Faculty members in these disciplines still focus on lower cognitive process skills while assessing students' learning outcome.

6. The instructional methods that the faculty could use to promote HOTS would be in-class active learning exercises, paraphrasing, use of analogies, real-time examples, frequent interaction with faculty, summarizing one or two peer reviewed papers, solving ill- structured and open ended problems and 
frequent writing assignments. Also, alternate teaching methods like use of analogies, group discussion, animation, case studies analysis and problem based learning will be useful in improving the higher order thinking skills of the students.

\section{AUTHOR INFORMATION}

Sowmya Narayanan, School of Social Sciences and Languages, VIT University, Vellore, Tamil Nadu, India. E-mail: sowmya_grn@yahoo.co.in

M. Adithan, Academic Staff College, VIT University, Vellore, Tamil Nadu, India

\section{REFERENCES}

James's Duderstadt, Engineering for a changing world: A road map to the future of Engineering, Practice, Research and Education, 'The Millennium Project', 2008, University of Michigan.

Fisch,K mc LeodS. Shift Happens. Retrieved November 11, 2010 from http:shifthappens.wikispaces.com. Atman C.J.D Kilgore and AMC Kenne "Characterizing Design Learning”, 2008, IEE.

Gluck 1992 quoted inThe Pursuit of WOW!: Every Person's Guide to Topsy-Turvy Times by Tom Peters Vintage 1994. ISBN: 0-679-75555-1 ,pp 259.

Robert B. Barr and John Tagg, From Teaching to Learning: A new paradigm for undergraduate education, 1995. Change.

Educating the Engineer of 2020, National Academy of Engineering, 2005, National Academy Press, Washington, D.C

Jean Pierre Bardet and Gisele Ragusa. Analysis of BOK (Body of Knowledge, Version 2) in Civil Engineering, American Society of Engineering Education, 2009.

Prince and Felder, Inductive Teaching and learning methods, definitions, comparisons and research bases, Journal of Engineering Education, 2006 Vol. 101.4, pp 123-137

Sowmya Narayanan and Adithan Munirathnam. (Unpublished report), Application of Bloom's Taxonomy of Educational Objectives as Problem Solving Tool in the Teaching Learning Process in an "Electrical Engineering Course" 2012.

Anderson Lorin W., David R. Krathwohl, et al, A taxonomy for learning, teaching and assessing; a Revision of Bloom's Taxonomy of Educational Objectives, (2001), Longman, New York.

Anderson LW and Sosnaik, Blooms Taxonomy, A forty year retrospective, Ninety third year book of the National society for the study of education, part @ Chicago, Il 1994, University of Chicago Press.

Teaching and Learning Excellence, sponsored by University of Wisconsin-Madison Teaching Academy, 2003 .http://www.odu.edu/educ/roverbau/Bloom/blooms_taxonomy.htm

Cruz, E. Encyclopedia of Educational Technology: Bloom's Revised Taxonomy, (2003). Retrieved November 19, 2007 from http://coe.sdsu.edu/eet/Articles/bloomrev/

Huitt, W. “Critical Thinking: an overview." Educational Psychology Interactive. Valdosta, GA: Valdosta State University, 1998. Web Retrieved 15 Jan 2011

fromhttp://www.edpsycinteractive.org/topics/cogsys/critthnk.html

Sally P. Springer, Georg Deutcsh, Left Brain, Right Brain: Perspectives from Cognitive Neuroscience, 1993.

Annette Mallory Donawa, Critical thinking and the impact of critical thinking instruction on minority engineering students at a public urban higher education institution, 2003 


\section{APPENDIX 1}

\section{BLOOMS TAXONOMY}

Benjamin Bloom created this taxonomy for categorizing different levels of competency to be developed in learning a subject. The taxonomy also provides a useful structure for categorizing test questions.

\section{Competence \\ Skills Demonstrated \\ Question Cues}

\section{Lower Order thinking Skills (LOTS)}

\begin{tabular}{|c|c|c|c|c|}
\hline Kno wledge & $\begin{array}{ll}\text { - } & \text { Observation and recall of } \\
\text { information (from memory) } \\
\text { - } \quad \text { Knowledge of dates, events, } \\
\text { places } \\
\text { - } \quad \text { Knowledge of major ideas } \\
\text { - Knowing of subject matter }\end{array}$ & $\begin{array}{l}\text { List } \\
\text { Define } \\
\text { Tell } \\
\text { Describe } \\
\text { Identify }\end{array}$ & $\begin{array}{l}\text { Show } \\
\text { Label } \\
\text { Collect } \\
\text { Where } \\
\text { Tabulate }\end{array}$ & $\begin{array}{l}\text { Quote } \\
\text { Name } \\
\text { Who } \\
\text { When }\end{array}$ \\
\hline Comprehension & $\begin{array}{l}\text { - } \quad \text { Understanding information } \\
\text { - } \quad \text { Trasp meaning } \\
\text { context knowledge into new } \\
\text { - Interpret facts, compare, } \\
\text { - } \quad \text { Ontrast } \\
\text { - } \quad \text { Predict group, infer causes } \\
\text { - }\end{array}$ & $\begin{array}{l}\text { Summarize } \\
\text { Describe } \\
\text { Interpret } \\
\text { Contrast }\end{array}$ & $\begin{array}{l}\text { Predict } \\
\text { Associate } \\
\text { Distinguish } \\
\text { Estimate }\end{array}$ & $\begin{array}{l}\text { Differentiate } \\
\text { Discuss } \\
\text { Extend }\end{array}$ \\
\hline
\end{tabular}

\section{Higher Order Thinking Skills (HOTS)}

\begin{tabular}{|c|c|c|c|c|}
\hline Application & $\begin{array}{l}\text { - Use information } \\
\text { - Use methods, concepts, } \\
\text { - } \quad \text { Solve problems using required } \\
\text { skills or knowledge }\end{array}$ & $\begin{array}{l}\text { Apply } \\
\text { Demonstrate } \\
\text { Calculate } \\
\text { Complete } \\
\text { Illustrate }\end{array}$ & $\begin{array}{l}\text { Show } \\
\text { Solve } \\
\text { Examine } \\
\text { Modify } \\
\text { Relate }\end{array}$ & $\begin{array}{l}\text { Change } \\
\text { Classify } \\
\text { Experiment } \\
\text { Discover }\end{array}$ \\
\hline Analysis & $\begin{array}{ll}- & \text { Seeing patterns } \\
- & \text { Organization of parts } \\
\text { - } & \text { Reorganization of hidden } \\
& \text { meanings } \\
\text { - } & \text { Identification of components }\end{array}$ & $\begin{array}{l}\text { Analyze } \\
\text { Separate } \\
\text { Order } \\
\text { Infer }\end{array}$ & $\begin{array}{l}\text { Connect } \\
\text { Classify } \\
\text { Arrange } \\
\text { Divide }\end{array}$ & $\begin{array}{l}\text { Compare } \\
\text { Select } \\
\text { Explain }\end{array}$ \\
\hline Synthesis & $\begin{array}{l}\text { - Use old ideas to create to create } \\
\text { new ones } \\
\text { - } \quad \text { Generalize from given facts } \\
\text { Relate knowledge from several } \\
\text { - } \quad \text { Preas/ disciplines } \\
\end{array}$ & $\begin{array}{l}\text { Combine } \\
\text { Integrate } \\
\text { Modify } \\
\text { Rearrange } \\
\text { Substitute }\end{array}$ & $\begin{array}{l}\text { Plan } \\
\text { Create } \\
\text { Design } \\
\text { Invent } \\
\text { What If? }\end{array}$ & $\begin{array}{l}\text { Compose } \\
\text { Formulate } \\
\text { Prepare } \\
\text { Generalize } \\
\text { Rewrite }\end{array}$ \\
\hline $\begin{array}{l}\text { Evaluation } \\
\text { (Judgment) }\end{array}$ & $\begin{array}{l}\text { - Compare and discriminate } \\
\text { between ideas } \\
\text { - } \quad \text { Assess value of theories, } \\
\text { presentations } \\
\text { - Make choices based on } \\
\text { - } \quad \text { Veasoned argument } \\
\text { - Recognize subjectivity }\end{array}$ & $\begin{array}{l}\text { Assess } \\
\text { Decide } \\
\text { Rank } \\
\text { Grade } \\
\text { Test }\end{array}$ & $\begin{array}{l}\text { Recommend } \\
\text { Convince } \\
\text { Select } \\
\text { Judge } \\
\text { Measure }\end{array}$ & $\begin{array}{l}\text { Discriminate } \\
\text { Support } \\
\text { Conclude } \\
\text { Compare } \\
\text { Summarize }\end{array}$ \\
\hline
\end{tabular}

